\title{
Verdens sjeldneste sykdom
}

\author{
De fleste pasienter lider av vanlige sykdommer, men de sjeldne sykdommene fikk uforholds- \\ messig mye oppmerksomhet i medisinstudiet. Det ga opphav til beskrivelsen av sykdom som \\ ingen ennå har sett.
}

Visste du at verdens sjeldneste sykdom er beskrevet i Norge? Det vil si den er ikke oppstått ennå, men en gang i fremtiden dukker den nok opp. Jeg har et nært personlig forhold til denne sykdommen, for den har forfulgt meg i årevis. Det begynte med at jeg var medisinstudent i Oslo i 1960-årene, og den gangen var Rikshospitalet det mest avanserte sykehuset $\mathrm{i}$ Norge. Hit kom pasienter fra hele landet med de merkeligste, sjeldneste og mest vanskelige sykdommer som kunne tenkes. Det fikk studentene merke: Jo mer sjelden en sykdom var, desto bredere omtale fikk den i forelesningene. Derimot hørte vi knapt om alminnelige sykdommer som feilte folk flest og som vi virkelig kom til à se i praksis. Utover i den kliniske delen av studiet irriterte jeg meg grenseløst over alle disse sjeldne sykdommene som vi måtte høre om i dobbeltforelesninger fordi vi aldri kom til å se dem igjen noen gang. Denne skikken forplantet seg, og på anatomen ble det holdt en dobbeltforelesning om podocytten - denne merkelige og sjeldne cellen som sitter på glomerulusmembranen i nyren. Den har lange fotliknende utløpere, hvilket forklarer navnet: fotcellen.

Siden tok det meg mer enn fem år å skrive og omskrive en bitte liten artikkel med tittelen «Sjeldne sykdommer», som ble publisert i Terapeutiske Fremskritt, informasjonsbladet til Apotekernes Laboratorium i Oslo. Men da artikkelen først kom på trykk, slo den ned som en bombe. Mange leger og studenter moret seg over harselasen over legene på Rikshospitalet og «finmedisinen». Siden ble den omsatt til engelsk og utgitt i USA i The Journal of Irreproducible Results (1). Påstanden om at det virkelig fantes sykdommer som var så sjeldne at de ikke hadde forekommet ennå ble tatt alvorlig, og ikke lenge etter var den tatt inn i The Guinness Book of Records: «The rarest disease in the world, not yet described, but predicted by a Norwegian medical doctor» (2). Jeg fikk også sendende mikroskopiske snitt fra kolleger som lurte på om en nyretumor de hadde funnet kunne være et podocytom. En tid kunne jeg også sole meg i berømmelsen over å ha beskrevet verdens sjeld- neste sykdom, og artikkelen ble trykt i flere engelske, tyske og amerikanske bøker om medisinske rariteter. Men det endte ikke noe bra: Etter noen år ble sykdommen tatt ut av Guinness' Rekordbok. Selv for dem var sykdommen for sjelden. Egentlig beviste det jo at jeg hadde rett, men likevel forsvant jeg i glemselen. Lærdommen er også at en spøk kan bli tatt alvorlig.

Imidlertid har det kommet enkelte vitenskapelige artikler i de siste ti årene der man har funnet immunhistokjemiske markører for podocytter i nyresvulster (3). Den medisinske forskningen er nok derfor like i hælene på meg, og jeg skal passe godt på!

Om forfatteren, dvs. undertegnede, er det følgende å fortelle: patolog, født i 1940, og også den omtalte medisinstudent i artikkelen som trodde han hadde fått hestehoste. Det vakte oppstandelse på Veterinærhøgskolen. Fordi alle forskere siterer seg selv, og siden jeg aldri hadde blitt sitert noen gang, satte jeg inn referansen til samme artikkelen etter den første setningen: «Sjeldne sykdommer ser man vanligvis ikke ofte (3)».

\section{Ole Didrik Lærum}

ole.laerum@gades.uib.no

Ole Didrik Lærum (f. 1940) er professor (adj.) ved Københavns Universitet og professor emeritus ved Gades institutt, Universitetet i Bergen.

\section{Litteratur}

1. Laerum OD. Rare diseases. The Journal of Irreproducible Results 1972; 19: 61-3 (amerikansk utgave).

2. McWhirter N, Greenberg S, red. Guinness Book of Records. 24. utg. Enfield, GB: Guinness Superlatives, 1977, 85 1+ flere senere utgaver, inklusive de norske).

3. Looi L-M, Cheah P-L. An immunohistochemical study comparing clear cell sarcomas of the kidney and Wilm's tumor. Pathology 1993; 25: 106-9. 


\section{Sjeldne sykdommer}

\section{Ole Didrik Lærum**}

(Fra: Institutt for generell og eksperimentell patologi, Universitetet i Oslo.

Sjef: Professor dr.med. Olav Hilmar Iversen.)

Sjeldne sykdommer ser man vanligvis ikke ofte (3). Når en av dem dukker opp, er det derfor naturlig å skrive om det, fortrinnsvis i form av en kasuistikk.

Slike kasuistikker har gjerne et pussig fellestrekk: Man skriver om en sykdom man har observert et eller to tilfeller av, fordi den er så sjelden. Og så konkluderes det med at denne sykdommen slett ikke er så sjelden likevel; ja, man bør faktisk være oppmerksom på den i praksis. Sitat: «Bare iløpet av siste 30 -årsperiode har vi hatt to slike tilfeller her i landet.» Slike kasuistikker kan beskrive flere forskjellige typer rare og uvanlige sykdomsbilder.

Vi skal gi en liten oversikt over hva slags typer det dreier seg om, og etterpå gi en analyse av slike sykdommers indre vesen, egenart og forekost $i$ relasjon til både vårt daglige og vårt universelle sjeldenhetsbegrep.

\section{TYPER AV UVANLIGE SYKDOMMER \\ 1) Sjeldne sykdommer som ikke er så ualminnelige likevel, på grunn av at de ikke diagnostiseres.}

Folk blir ikke gjort oppmerksom på at de lider av disse og går derfor helt intetanende omkring. Vi kan godt si at disse sykdommene ikke er skikkelig markedsført. Her kan radio, TV og presse gjøre mye. Det gjør de også.

Hver gang det er kampanjeuke for en bestemt sykdom, godt understøttet av våre massemedia, strømmer folk til legekontorene dagen etter. Hvis vi dertil fikk en sjeldenhetsuke, kunne man kanskje fiske en rekke rariteter.

Et kasus illustrerer dette:

NN, mann, f. 1940, daværende medisinsk student, leste våren $1963 \mathrm{i}$ avisen at det hadde opptrådt smittsom hestehoste på Bjerkebanen i Oslo. Dette forløp ukomplisert. Vinteren 1964 leste han på ny i avisen at det hadde kommet hestehoste, denne gang i stallene på Øvrevoll. Etter den siste artikkelen følte han seg ikke bra. I løpet av noen dager utviklet deg seg snue, febrilia og en sterk, vedvarende hoste. Hosteanfallene startet pianissimo, tempoet var først andante, deretter fult av en sterk crescendo opp til forzato (NN var ivrig amatørmusiker), og munnet så ut i en lengre passasje med ritardando og sterkt kneggende hoste- støt. NN oppsøkte lege, som aldri hadde hørt om hestehoste hos mennesker. NN måtte gå med uforrettet sak, men ble senere spontant helbredet. NN mener bestemt at det var avisartikkelen som utløste sykdommen.

En annen lidelse som ofte ikke diagnostiseres, er det syndrom som først ble beskrevet av Getz (2), nemlig tredje-ventrikkel-flimmer med forhøyet cisternetrykk. Syndromet forekommer gjerne etter en belivet aften og blir populært benevnt som «dagen derpå». Her ser vi en relativt alminnelig tilstand som ikke blir erkjent fordi det er så vanskelig å registrere om en pasient har tredje-ventrikkel-flimmer eller ikke.

\section{2) Sykdommer som er sjeldne fordi} de er avhengig av bestemte tidsepoker Uttrykket «et astmatisk lokomotiv» er velkjent $i$ litteraturen. Men det er få som er klar over hvorfor astma hos lokomotiver ikke forekom på 1700-tallet. Dette skyldes at først måtte Stephenson oppfinne damplokomotivet. Nå er tilstanden igjen blitt sjelden. Den sees i alle fall ikke på våre sykehusavdelinger. Grunnen må åpenbart være at damplokomotivet nå er erstattet av dieselog elektriske lokomotiver.

\section{3) Sykdommer som er sjeldne}

fordi de er sjeldne

Slike sykdommer blir under forelesninger gjerne presentert over en dobbelt-time. Omtalen avsluttes som regel i følgende ordelag: «Tilstanden er slett ikke så sjelden og er derfor viktig å være oppmerksom på. Enhver som tilbringer livet sitt på en indremedisinsk avdeling vil kunne ha gode sjanser til å få se et tilfelle av sykdommen. Selv har jeg sett ett tilfelle. Det var før krigen.»

Går vi nå et skritt videre, kan vi formulere følgende problemstilling, som er utgangspunkt for den aktuelle undersøkelse: Fins det sykdommer som er så sjeldne at de ennå ikke har forekommet?

Hvis det gjør det - og det må vi gå ut fra så er der er i så fall to typer som føyer seg til i rekken:

\section{4) Sykdommer som ennå ikke har} forekommet, men som vil forekomme en gang, enten før eller senere Et typisk eksempel på en slik lidelse er månestøvforgiftning.
En annen viktig, hittil ikke beskrevet sykdom i denne gruppen er podocytom $\mathrm{i}$ nyren. Podocyttene er som kjent epiteliale celler som står festet med tallrike fotprosesser til membranen i glomerulusnøstet og deltar i filtreringen av urinen (Fig. 1). Disse cellene har ennå ikke laget noen tumor.

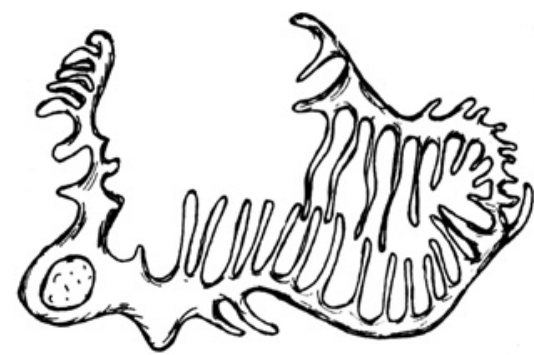

Fig. 1 Normal podocytt

Men en gang vil de. Det blir et podocytom, en høyt differensiert benign tumor, som først ble forutsagt og beskrevet i 1971 i denne artikkelen (Loerum's tumor). Det karakteristiske elektronmikroskopiske bilde ved denne tilstand er at fotprosessene går i utakt (Fig. 2)

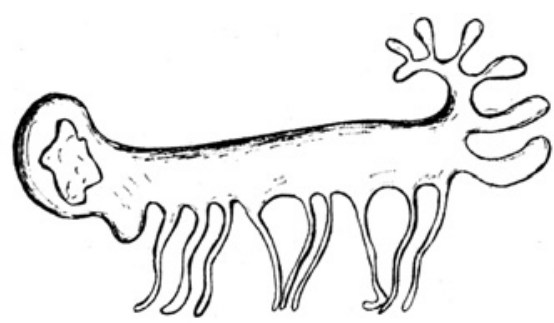

Fig. 2 Detalj fra podocytom. Bemerk fot nr. 4 og 7

\section{5) Sykdommer som ennå ikke har forekommet og som heller ikke vil forekomme noen gang}

Disse er meget sjeldne og har liten praktisk klinisk betydning. Det er ikke nødvendig for almenpraktikeren å kunne noe om dem.

*Ethvert medisinsk tidsskrift med respekt for seg selv bringer originalartikler. Imidlertid har også TF respekt for seg selv. I dette nummer ser vi oss derfor i stand til å bringe en særlig original originalartikkel. Forfatterens synspunkter deles ikke nødvendigvis av redaksjonen.

**Terapeutiske Fremskritt, 1971, 17, 46-50. 


\section{DISKUSJON}

Er vårt sjeldenhetsbegrep foreldet? Det er $i$ alle fall upresist. Som tidligere demonstrert brukes ordet «sjelden» i medisinske forbindelser fortrinnsvis i artikler som skrives fordi en sykdom er sjelden, men hvor man prøver å vise at den i virkeligheten er hyppig. Artikkelen blir derfor antatt til publisering både fordi sykdommen er så sjelden og fordi den samtidig synes hyppig.

Samtidig er vårt sjeldenhetsbegrep flytende. Nye sjelden sykdommer kommer. Andre sjeldne sykdommer blir borte og forekommer ikke mer. Det er derfor en tanke å ta vare på visse sjeldne sykdommer før de forsvinner helt.

Videre er vårt sjeldenhetsbegrep stadig utsatt for angrep og risikerer å bli uthulet og miste sin praktiske betydning. Vi må derfor passe på ikke å bruke ordet «sjelden» så ofte at det blir alminnelig. Vi må heller ikke la oss vill- lede når sjeldenhetsbegrepet blir trukket inn ved banale lidelser som forekommer på en uvanlig måte. Typisk eksempel på en slik tilstand er caries hos tannløse.

Tar vi samtlige av våre nåværende kjente sykdommer og grupperer dem etter forekomst, viser det seg at gruppen «alminnelige sykdommer» bare omfatter et relativt lite antall sykdomsenheter. Gruppen «ualminnelige sykdommer» er langt større. Men tar vi så gruppen «sjeldne sykdommer», så omfatter bare en liste over navnene en tykk bok (2). Således eksisterer det egentlig en vrimmel av obskure sykdommer og syndromer. Hver enkelt av dem ses riktignok svært sjelden, men til gjengjeld er det mange av dem. Tilsammen utgjør de derfor en betydningsfull gruppe, som sammenlagt kanskje blir noe av det viktigste vi har med å gjøre i medisinen.

Konklusjon: sjeldenheter er ikke lenger noen sjeldenhet. Hva er de da?

\section{SUMMARY}

A survey of our concept of rare diseases is given. The author demonstrates that there exist diseases which hitherto never occurred, som of these will never occur in the future either. A new tumour, podocytoma («Larum's tumour»), a benign lesion of the kidney, is described, to illustrate the pathology of a clinical entity without known existence.

It is concluded that because there are so many different types of them, rare diseases should no longer be considered as uncommon.

\section{Litteratur}

1. Getz B.: Foredrag på burlesk disputas, Medicinerforeningen, Oslo 13/4 1961.

2. Lieber, B. Olbrich, G.: Wörterbuch der klinischen Syndrome. Urban \& Schwarzenberg. München Berlin 1959, $730 \mathrm{pp}$

3. Lærum, O.D.: Sjeldne sykdommer. Terapeutiske Fremskritt, 1971, 17, 46-50. 